\title{
Diversity dynamics of ammonoids during the latest Bajocian and Bathonian (Middle Jurassic) in the epicratonic Polish Basin
}

\author{
Michał Zatoń
}

Received: 29 September 2010 /Revised: 2 November 2010/Accepted: 17 November 2010/Published online: 11 December 2010

(C) The Author(s) 2010. This article is published with open access at Springerlink.com

\begin{abstract}
Results of the analysis of Middle Jurassic (latest Bajocian-Bathonian) ammonoid diversity patterns in the Polish Basin are reported. The data used in this study are based on a large number of ammonoid specimens, collected bed-by-bed, from the Polish Jura in south-central Poland, as well as on existing literature. The ammonoid diversities, both at the genus and species levels, have been calculated for particular ammonite zones and subzones and compared with the regional transgressive-regressive cycles for the Polish Lowlands and Hallam's global sea-level curve. The patterns of ammonoid diversity dynamics seem to be well correlated with global sea-level fluctuations. Particular diversity peaks correspond with major transgressive episodes. Three main regional bio-events related to transgressions have been distinguished for the Polish Basin: (1) the Latest Bajocian (Bomfordi Subchron) bio-event is related to a short-lasting immigration of Tethyan ammonoids; (2) a late Early Bathonian (Tenuiplicatus Chron) bio-event corresponds to a proliferation of Asphinctites tenuiplicatus (Brauns), most probably as a result of transgression-driven eutrophication of a shallow-marine environment; during this time, the immigration (passive dispersion?) of some single Tethyan species is also observed; and (3) a Late Bathonian (Hodsoni and Orbis chrons) bio-event corresponds to the highest ammonoid species diversity peaks and most probably is related to the major transgression during the Bathonian, which allowed easy migration of several species via several newly opened sea-ways.
\end{abstract}

\section{Zatoń $(\bowtie)$}

Faculty of Earth Sciences, University of Silesia,

Będzińska 60,

41-200, Sosnowiec, Poland

e-mail: mzaton@wnoz.us.edu.pl
Keywords Ammonoids · Jurassic · Diversity Transgression $\cdot$ Regression $\cdot$ Poland

\section{Introduction}

Factors controlling the changes in ammonoid assemblage composition may be both biotic and abiotic in nature (e.g., Sandoval et al. 2002). Even slight perturbations in a marine environment may significantly influence shallow-water, stenotopic organisms (e.g., Kauffman 1977, 1984; Hallam and Wignall 1999), including ammonoids (Kennedy and Cobban 1976; Hallam 1996; Westermann 1996; Sandoval et al. 2001). The relationship between ammonoid diversity patterns and sea-level changes has been demonstrated by several workers (see Wiedmann 1973, 1988; Kauffman 1977, 1984; Saunders and Swan 1984; Marcinowski and Wiedmann 1988; Kutek et al. 1989; Hoedemaeker 1995; Kutek and Marcinowski 1996; Wiedmann and Kullmann 1996; O’Dogherty et al. 2000; Sandoval et al. 2001, 2002; Westermann 2001; Marcinowski and Gasiński 2002; Ruban 2007). Sandoval et al. (2002) confirmed such a relationship during their analysis of the Middle Toarcian-Lower Bajocian ammonoids of France, Spain, Morocco and Italy. Such a phenomenon may also be observed amongst Palaeozoic (Namurian) ammonoids in which not only diversity but also disparity (variety of morphological forms) changes were observed (Saunders and Swan 1984). Recently, Ruban (2007) investigated the diversity of different Jurassic faunal groups and found that only ammonites seem to have been influenced by transgressions and regressions in the Caucasus Mountains (see also Ruban 2010).

Generally, during transgressions, the increase of ecospace favoured the development of new taxa inhabiting new 
areas (Wiedmann 1973; Hallam 1987; Hoedemaeker 1995). During regressions, changes in temperature and salinity (increasing environmental stress) in shallow epicontinental seas drove several stenotopic taxa to extinction (see Wiedmann 1973, 1988; Kauffman 1977, 1984; Hallam 1987, 1996; Hoedemaeker 1995; Vermeij 1995; Hallam and Wignall 1999; O'Dogherty et al. 2000; Sandoval et al. 2001, 2002; Twitchett 2006). Also, importantly, transgressions and regressions changed palaeogeographic and palaeotopographic situations by opening or closing sea-ways enabling or disabling the migrations of several species (e.g., Dommergues et al. 2009). Interestingly, Ruban (2010) recently found that, in the Bajocian of the Caucasus, the transgressions coincided with impoverishments of ammonite assemblages, whereas regressions coincided with their diversification. The patterns observed by Ruban (2010), however, need further research. Thus, sea-level changes may have operated both directly and indirectly on different taxa, and it seems that ammonoids are very useful tracers of transgressions and regressions on both regional and global scales. They may have far richer utility than other, especially benthic, groups of marine invertebrates (cf. Ruban 2007).

In this paper, the relationship of ammonoid diversity patterns and transgressive-regressive cycles in the Middle Jurassic Polish Basin during the latest Bajocian and Bathonian is described, and ammonoid diversity dynamics during particular chrons and subchrons are discussed in the context of the sea-level-related environmental and palaeobiogeographic changes.

\section{Palaeogeography, geology and palaeoenvironments}

\section{Palaeogeographic background}

During the Middle Jurassic, the Polish Basin was located at ca. $40^{\circ} \mathrm{N}$ latitude as a part of the Laurasian continent (Golonka 2000) (Fig. 1a). As the easternmost extension of the large Mid-European Epicontinental Basin, the Polish Basin was bordered by the Fennoscandian land to the north, Belorussian and Ukrainian lands to the east, Bohemian land to the west and pre-Carpathian land to the south (see Dadlez 1989; Ziegler 1990; Feldman-Olszewska 1997) (Fig. 1a).

The basin was undoubtedly connected with the Tethys, and all transgressive pulses from the Aalenian through Bathonian were related to this ocean (Dayczak-Calikowska et al. 1997). However, their main pathways are still unclear in Poland. Dayczak-Calikowska and Moryc (1988) suggested the East-Carpathian Gate in the south-east via the Mid-Polish Trough as the main path. Świdrowska (1994), on the other hand, suggested that the Aalenian transgression, at least, entered from the west (see also Feldman-
Olszewska 1997). The Moravian Gate, situated in the south-west, is considered to have been closed at least to the Late Bathonian transgression (Dayczak-Calikowska and Moryc 1988; see also Feldman-Olszewska 1997).

In the Middle Jurassic, the Polish Basin broadened gradually, attaining its greatest area in the Late Bathonian, when nearly the whole of the Polish Lowlands was covered by the sea (Matyja and Wierzbowski 2006). During the Bajocian and Bathonian, the sedimentation in the Polish Basin was dominated by siliciclastics, derived primarily from the Fennoscandian and Bohemian lands (Dadlez 1997; Marynowski et al. 2007).

Geology and stratigraphy

The classic area where the Middle to Upper Jurassic deposits are exposed in a large number of localities is the so-called Polish Jura. Polish Jura is a monoclinally extended structure spreading from south-east to northwest of the Cracow-Wielun Upland in southern and south-central Poland (Fig. 1b-c). Generally, the Middle Jurassic deposits in that area may directly rest upon Palaeozoic and Lower Jurassic deposits, and are directly overlain by Upper Jurassic carbonates or thin Quaternary cover (e.g., Różycki 1953; Dayczak-Calikowska et al. 1997; Kopik 1998).

The Upper Bajocian through Bathonian epicratonic sediments under study consist of a monotonous sequence of darkgrey to black and poorly consolidated siliciclastics with a variable content of a coarser fraction. They are intercalated by massive siderites, as well as carbonate concretions, occurring as single bodies and more or less continuous horizons. This complex in the Polish Jura is known as the Ore-bearing Częstochowa Clay Formation (e.g., Dayczak-Calikowska et al. 1997; Kopik 1998; Majewski 2000; Matyja and Wierzbowski 2000; Zatoń and Marynowski 2006; Szczepanik et al. 2007), and the sediments under discussion are usually simply referred as to clays. They rest nearly horizontally or dip very gently toward the north-east. They are often capped by condensed Callovian limestones, sandstones, sandylimestones or marls (e.g., Dayczak-Calikowska et al. 1997; Dembicz and Praszkier 2003).

The Middle Jurassic ore-bearing clays are widely exposed in several brick-yards scattered in the southern to northern part of the Polish Jura (see Matyja et al. 2006a, b, c; Marynowski et al. 2007; Wierzbowski and Joachimski 2007; Zatoń et al. 2009). On the basis of lithology, thicknesses and stratigraphic completeness of the orebearing clays, the Polish Jura area was divided into northern and southern sedimentary regions by Różycki (1953). The northern sedimentary region (the area north of Ogrodzieniec up to the Wielun area; see Fig. 1c), unlike the southern one (the Ogrodzieniec and southern areas), is 

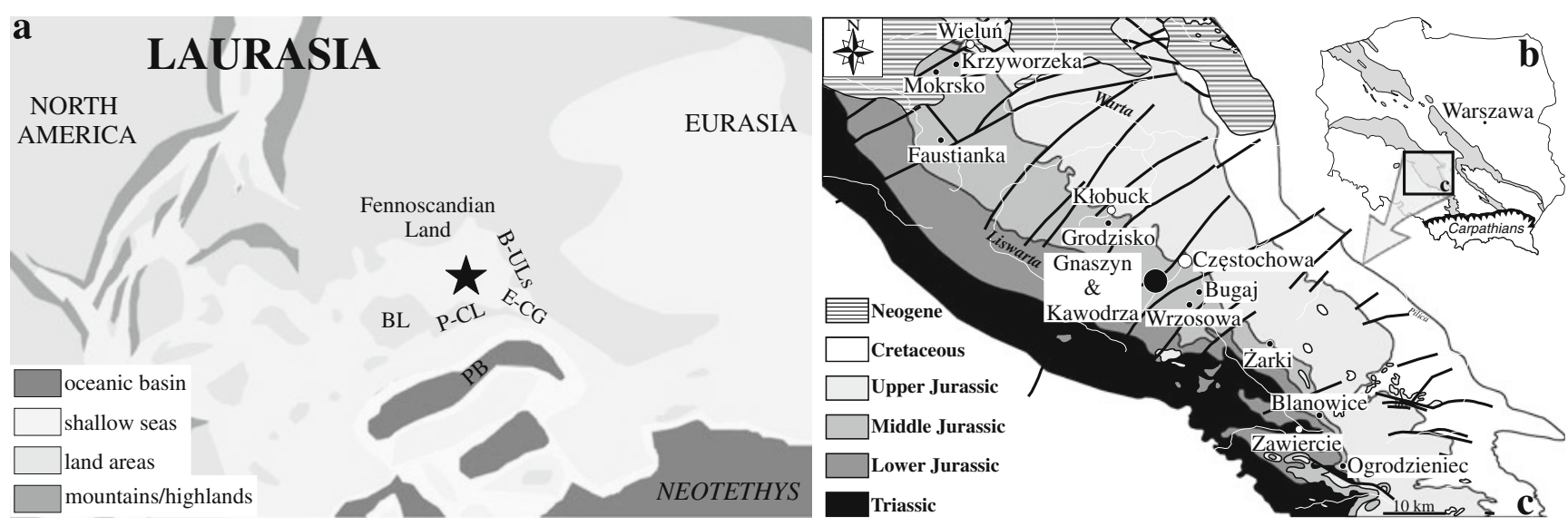

Fig. 1 a Location of the Polish Basin (star) on the background of the Middle Jurassic palaeogeography (simplified and modified after Golonka 2000). BL Bohemian land, $B$-Uls Belorussian and Ukrainian lands, $E-C G$ East-Carpathian Gate, $P-C L$ Pre-Carpathian land, $P B$

characterised by a more fully developed and thicker sequence of the ore-bearing clays.

Based on ammonite faunas, it is clear that the exposed orebearing clays range from the Parkinsoni Zone of the Upper Bajocian up to the Orbis Zone of the Upper Bathonian (Kopik 1998; Matyja and Wierzbowski 2000; Matyja et al. 2006a, b, c; Zatoń 2007a, 2010a, b). The basal Middle Bathonian Progracilis Zone was documented north of Częstochowa (see Matyja and Wierzbowski 2000), but so far no guide ammonites have been presented, so its position within the clays is still unknown. Poulsen (1998), based upon dinocysts, assumed that the higher zone of the Upper Bathonian - the Discus Zone - may be present in the northern part of the Polish Jura. Quite recently, Barski et al. (2004), also using dinocysts, confirmed the presence of the Discus Zone in the southern part of the area. However, this zone has so far not been recognised from ammonites. It must also be noted that, in the past, even older (Lower Bajocian) deposits were exposed in the Polish Jura area (e.g., Kopik 1967).

\section{Remarks on palaeoenvironments}

During the Bajocian and Bathonian, the Polish Basin was characterised by a monotonous sedimentation regime consisting mainly of siliciclastic clays and muds. The sedimentation of the ore-bearing clays in the northern sedimentary region was basically continuous and has been interpreted to have proceeded in a quiet marine environment, generally below the storm wave-base (Matyja et al. 2006a, b, c). However, in some intervals of the Upper Bajocian and Bathonian, signs of sedimentation pauses and/or erosion occur in a form of exhumed concretions (hiatus concretions) that were intensively bored and encrusted (Zatoń et al. 2006; Zatoń and Taylor 2009a). The concretions are also characterised by deeply truncated borings indicating that a strong hydrodynamic
Pieniny Basin. b Map of Poland with Jurassic deposits indicated (shaded areas) after removal of the Cenozoic cover. c Geological map of the Polish Jura area with sampled localities indicated (black circles) (modified after Zatoń and Taylor 2009a)

conditions (likely storms) influenced them episodically on the sea-bottom. In the southern sedimentary region, sedimentation had taken place in shallower environments. According to Różycki (1953), the southern region represented a shallower, marginal marine facies zone where a reduction of thickness, hiatuses and coarser grain fractions are evident. The strong water agitation is not only evidenced by hiatus concretions (Zatoń et al. 2006) but also from heavily encrusted, large oncoids (see Zatoń and Taylor 2009b, 2010).

Geochemical and petrographical investigation of the Upper Bajocian and Bathonian clay deposits of both the northern and southern sedimentary regions indicated that during sedimentation the bottom waters were oxygenated and any evidence of anoxia, both at the bottom and in the water column, is lacking (Marynowski et al. 2007; Szczepanik et al. 2007). This is wellsupported by the diverse benthic fauna (e.g., foraminifers, various molluscs, echinoderms, arthropods, bryozoans, annelids) and trace fossils (see Różycki 1953; Matyja et al. 2006a, b, c; see also Zatoń et al. 2009 for a short review). Recent stable isotopic studies of calcareous biota (Wierzbowski and Joachimski 2007) indicate that bottom water palaeotemperatures ranged from 7.4 to $10.1^{\circ} \mathrm{C}$ and that surface waters were warmer but probably below $18^{\circ} \mathrm{C}$ (but see Marynowski et al. 2007) in the Late Bajocian-Bathonian epicratonic sea of south-central Poland. Such palaeotemperature values are rather low for the generally warm Jurassic period (e.g., Hallam 1985), but in agreement with a palaeoclimatic study of Price (1999) who suggested a global cooling in the Bajocian and Bathonian.

\section{Materials and methods}

Amongst the macroinvertebrate groups inhabiting the Late Bajocian-Bathonian Polish Basin, ammonoids are the best- 
studied, being the subject of several palaeontological and biostratigraphical works (e.g., Różycki 1953, 1955; Potocki 1972; Korcz 1973; Dayczak-Calikowska et al. 1988, 1997; Majewski 1997; Kopik 1974, 1979, 1998, 2006; Kopik et al. 1980; Matyja and Wierzbowski 2000, 2001, 2003; Matyja et al. 2006a, b, c; Zatoń and Marynowski 2006; Zatoń 2007a, b, 2008, 2010a, b). They thus provide excellent material for study of diversity dynamics.

For this research, ammonites have been gathered from the Polish Jura, an area situated in south-central Poland where the exposures of Middle and Upper Jurassic sedimentary rocks are abundant and easily accessible. Thus, in light of this research, the area of the Polish Jura may be considered as a reference point for studying the Upper Bajocian-Bathonian ammonoids of the epicratonic Polish Basin.

In order to provide accurate data, the number of genera and species for each of the Upper Bajocian-Bathonian ammonite zones and subzones have been counted. To do so, the data about the ammonoid genera/species number were selected from the works of Zaton (2007a, 2010a, b), where the ammonoids studied were collected from stratigraphically well-defined horizons. All the indeterminable specimens were excluded from the analysis. If the correspondence of macro- and microconchs of particular species is known, as in the case of the Middle Bathonian Morrisiceras morrisi (Oppel) (see Zaton 2008), they are treated as the same species. Since there are different approaches to the taxonomy of ammonoids (see discussion in, e.g., Sandoval et al. 2001), the author has not used data presented in the form of just species lists (with no figured specimens) included in comprehensive works (e.g., Kopik et al. 1980; DayczakCalikowska et al. 1988, 1997; Kopik 1998). Nor were the species names provided for particular zones or subzones with no figured specimens in some recent papers (e.g., Matyja et al. 2006a, b, c) considered for the present study. Such an exclusion of listed but not figured species is crucial to avoid overestimating the number of species, which in fact, in some circumstances, might have been synonyms. The exception to this procedure, however, is the use of only those genera that have not been documented by Zaton (2007a, 2010a, b). This is because genera, in contrast to species, are usually assigned with greater objectivity by the ammonite workers. Each additional genus derived from the published lists is considered as an additional species. However, in the case where a listed genus is represented by two or more species, it is counted as one species to avoid any further species overestimation. Also, the ammonite species of uncertain or not exact stratigraphic provenance (e.g., Dayczak-Calikowska et al. 1988; Kopik 1974; Kopik et al. 1980) have been disregarded. The additional taxonomic data mentioned above were derived from the works of Kopik (1998, 2006), Matyja and Wierzbowski $(2000,2003)$ and
Matyja et al. (2006a, b, c). Using such a methodology for data gathering may exclude some true ammonoid species not listed by Zatoń (2007a, 2010a, b), but it avoids species overestimation within particular ammonite zones/subzones.

The ammonoid diversity has been presented as both genera and species numbers for each ammonite zones/ subzones investigated. The diversity curve of the latest Bajocian-Bathonian ammonoid faunas from the Polish Basin was then compared to the transgressive-regressive cycles distinguished for the Polish Lowlands by FeldmanOlszewska (1997) and the sea-level curve of Hallam (1988, 2001) The latter, in contrast to the sea-level curve constructed by the Exxon group (Haq et al. 1987), was established on the basis of classic European sections having well-recognised stratigraphy and located on a relatively stable craton (see also Hallam 1992).

\section{The ammonoid diversity patterns in the Polish Basin}

Following rather poor and monotonous ammonoid diversity, on both the genus and species levels (mainly the ammonites of the genus Parkinsonia), within the Upper Bajocian Parkinsoni Subzone, the first peak of ammonoid diversity is observed higher up in the Bomfordi Subzone, attaining seven genera and 12 species (Fig. 2; Table 1). Apart from ammonoids that are characteristic for the extra-Mediterranean areas, such as Parkinsonia, Strigoceras or Vermisphinctes, the ammonoids whose diversity and abundance is greatest in the Tethyan areas, such as Phylloceras, Nannolytoceras and Lissoceras (see, e.g., Galácz 1980), also occur and constitute a characteristic component of the whole assemblage.

During the Early Bathonian (Zigzag Chron), the ammonoid diversity drops (Fig. 2; Table 1). The lowest (two genera and five species) is noted for the Convergens Subchron dominated by Parkinsonia and Planisphinctes (Kopik 1998; Matyja and Wierzbowski 2000; Zatoń and Marynowski 2006; Zatoń 2007a). Somewhat higher, but still low (five genera and five species), diversity is noted for the Yeovilensis Subchron (Fig. 2; Table 1). The latter is characterised by the presence of oppeliids (Oxycerites), morphoceratids (Asphinctites, Berbericeras) and stephanoceratids (Cadomites) (Matyja and Wierzbowski 2003; Kopik 1998; Zatoń 2007a). Kopik (2006) has allegedly stated that true Tulites representatives, as Tulites cadus Buckman which he described, come from the Lower Bathonian of the Polish Jura. However, as the specimens mainly represent an old collection without any indication of the horizon they were collected from, their stratigraphic provenance is uncertain.

Yet higher ammonoid diversity (six genera and ten species) is noted in the uppermost part of the Lower Bathonian-Tenuiplicatus Zone (Fig. 2; Table 1). Especially interesting is a mass occurrence of dimorphic pairs of the 


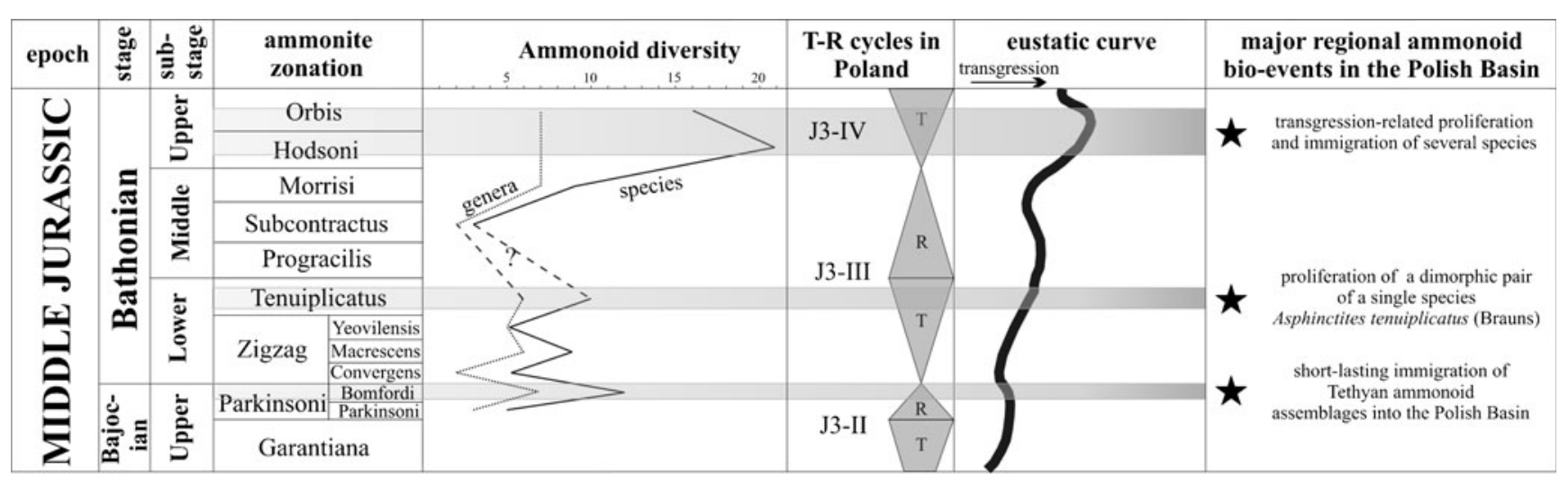

Fig. 2 Ammonoid diversity on the genus (dotted line) and species (solid line) level within particular ammonite zones and subzones, compared with the transgressive-regressive $(T-R)$ cycles distinguished for the Polish Lowlands (slightly modified after Feldman-Olszewska

morphoceratid species Asphinctites tenuiplicatus (Brauns) [=Asphinctites tenuiplicatus (Brauns) $[\mathrm{M}]$ and Polysphintites secundus (Wetzel) [m]; see Matyja and Wierzbowski 2000 , 2001) that occur both in Kawodrza Górna and Faustianka, the latter site located ca. $40 \mathrm{~km}$ north (Fig. 1c; see also Matyja and Wierzbowski 2000, 2001 for details). Apart from Asphinctites assemblages, oppeliids [Oxycerites (O.) yeovilensis Rollier [M \& m], Oxycerites (O.) seebachi (Wetzel), Oxycerites (Paroecotraustes) formosus (Arkell)] (see also Matyja and Wierzbowski 2000) and perisphinctids (Procerites $[\mathrm{M} \& \mathrm{~m}]$ and Wagnericeras
1997) and eustatic curve of Hallam $(1988,2001)$, together with major regional, transgressive-driven ammonoid bio-events for the Polish Basin

$[\mathrm{M}])$ occur, but in much smaller quantity. Single phylloceratid Calliphylloceras disputabile (Zittel) as phragmocones of large individuals, and again Lissoceras solitarium Zatoń \& Marynowski [m] known from the uppermost Bajocian Bomfordi Subzone also occur. However, the latter two species represent an insignificant component of the whole ammonoid assemblage here.

The ammonoid diversity for the basal Middle Bathonian Progracilis Zone is unknown. In the literature, the Progracilis Zone is either omitted (Kopik 1998) or united with the successive Subcontractus Zone (see Kopik 2006). A

Table 1 Ammonoid genera and their species number (in parentheses) in particular ammonite zones and subzones of the Polish Jura area

\begin{tabular}{|c|c|c|}
\hline Substage/zone/subzone & Ammonite taxa & References \\
\hline $\begin{array}{l}\text { Upper Bathonian/Orbis } \\
\text { Zone }\end{array}$ & $\begin{array}{l}\text { Oxycerites (4), Prohecticoceras (2), Procerites (2), Choffatia (5), } \\
\text { Epistrenoceras (1), Cadomites (1), Bullatimorphites (1), }\end{array}$ & Kopik (1998); Zatoń (2007a, b, 2010a, b) \\
\hline $\begin{array}{l}\text { Upper Bathonian/Hodsoni } \\
\text { Zone }\end{array}$ & $\begin{array}{l}\text { Calliphylloceras (1), Oxycerites (4), Cadomites (2), Procerites } \\
\text { (6), Wagnericeras (2), Choffatia (3), Bullatimorphites (3) }\end{array}$ & Kopik (1998, 2006); Zatoń (2007a, 2010a, b) \\
\hline $\begin{array}{l}\text { Middle Bathonian/Morrisi } \\
\text { Zone }\end{array}$ & $\begin{array}{l}\text { Calliphylloceras (1), Oxycerites (3), Prohecticoceras (1), } \\
\text { Procerites (1), Choffatia (1), Bullatimorphites (1), } \\
\text { Morrisiceras (1) }\end{array}$ & Kopik (2006); Zatoń (2007a, 2008) \\
\hline $\begin{array}{l}\text { Middle Bathonian/ } \\
\text { Subcontractus Zone }\end{array}$ & Oxycerites (2), Tulites (1) & Zatoń (2007a, b, 2010a, b) \\
\hline $\begin{array}{l}\text { Lower Bathonian/ } \\
\text { Tenuiplicatus Zone }\end{array}$ & $\begin{array}{l}\text { Calliphylloceras (1), Oxycerites (3), Lissoceras (1), Procerites } \\
\text { (3), Wagnericeras (1), Asphinctites (1) }\end{array}$ & $\begin{array}{l}\text { Matyja and Wierzbowski (2000, 2001); Zatoń and } \\
\text { Marynowski (2006); Zaton (2007a, 2010a, b) }\end{array}$ \\
\hline $\begin{array}{l}\text { Lower Bathonian/Zigzag } \\
\text { Zone/Yeovilensis } \\
\text { Subzone }\end{array}$ & $\begin{array}{l}\text { Oxycerites (1), Cadomites (1), Berbericeras (1), Morphoceras } \\
\text { (1), Asphinctites (1) }\end{array}$ & $\begin{array}{l}\text { Kopik (1998); Matyja and Wierzbowski (2003); } \\
\text { Zatoń (2007a, 2010a, b) }\end{array}$ \\
\hline $\begin{array}{l}\text { Lower Bathonian/Zigzag } \\
\text { Zone/Macrescens } \\
\text { Subzone }\end{array}$ & $\begin{array}{l}\text { Oxycerites (1), Cadomites (1), Procerites (1), Zigzagiceras (1), } \\
\text { Parkinsonia (2), Morphoceras (3) }\end{array}$ & Kopik (1998); Zatoń (2007a, 2010a, b) \\
\hline $\begin{array}{l}\text { Lower Bathonian/Zigzag } \\
\text { Zone/Convergens } \\
\text { Subzone }\end{array}$ & Parkinsonia (4), Planisphinctes (1) & Kopik (1998); Zatoń (2007a, 2010a, b) \\
\hline $\begin{array}{l}\text { Upper Bajocian/Parkinsoni } \\
\text { Zone/Bomfordi Subzone }\end{array}$ & $\begin{array}{l}\text { Phylloceras (1), Nannolytoceras (1), Lissoceras (2), Strigoceras } \\
\text { (1), Oxycerites (2), Vermisphinctes (1), Parkinsonia (4) }\end{array}$ & $\begin{array}{l}\text { Matyja and Wierzbowski (2000); Zatoń and } \\
\text { Marynowski (2006); Zatoń (2007a, 2010a, b) }\end{array}$ \\
\hline $\begin{array}{l}\text { Upper Bajocian/Parkinsoni } \\
\text { Zone/Parkinsoni Subzone }\end{array}$ & Cadomites (1), ?Leptosphinctes (1), Parkinsonia (3) & $\begin{array}{l}\text { Matyja and Wierzbowski (2000); Zatoń (2007a, } \\
\text { 2010a, b) }\end{array}$ \\
\hline
\end{tabular}


potential site where deposits of the Progracilis Zone may be present is Faustianka. There, the lower part of the exposure is definitely dated as the uppermost Lower Bathonian Tenuiplicatus Zone (e.g., Matyja and Wierzbowski 2000). Matyja and Wierzbowski (2000) have stated they have found ammonites (mainly Procerites) characteristic of the Progracilis Zone at Faustianka; however, they are not yet either described or illustrated. Therefore, for the time being, the characteristics of the Progracilis Zone together with its ammonite content are not known in the Polish Jura area.

The ammonoid diversity in the following Subcontractus Zone is very low (two genera and three species) (Fig. 2; Table 1). In Blanowice (Fig. 1c), only two species (Tulites subcontractus Buckman $[\mathrm{M}]$ and Oxycerites $(O$.) sp. ex gr. yeovilensis Rollier $[\mathrm{M}]$ ) have been documented (Zatoń 2007a, b, 2010a, b), and from the Częstochowa environs (Gnaszyn Dolny) just one, T. cadus Buckman [M], although the Oxycerites species may also occur there. Besides $T$. cadus Buckman and T. tulotus (Buckman), the species T. subcontractus (Morris \& Lycett) was also mentioned by Kopik $(1998,2006)$ from the Częstochowa environs.

This impoverishment of ammonoid diversity during the Subcontractus Chron may result from insufficient sampling, as the deposits of this zone were not well exposed in the Częstochowa area during fieldwork conducted by Zatoń (2007a), or are very reduced in the Blanowice locality (Zaton 2007b). However, as we brought together the data obtained by Zaton $(2007 \mathrm{a}, \mathrm{b}, 2010 \mathrm{a}, \mathrm{b})$ and that selected from the literature, it seems that during this chron the overall ammonite diversity was indeed low.

Higher up, in the Morrisi Zone, ammonoid diversity on the species level is a little bit higher (nine species) than on the genus level (seven genera), but generally the diversity on both taxonomic levels is quite similar (Fig. 2; Table 2). Among the species recorded, the most abundant is the morphologically widely variable Morrisiceras morrisi (Oppel) [M \& m] (see Zatoń 2008) and Oxycerites (O.) sp. ex gr. yeovilensis Rollier [M \& m]. Although the first is confined only to the Morrisi Zone, the latter species also occurs in the older Subcontractus Zone.

The highest ammonoid diversity is noted in the Upper Bathonian Hodsoni Zone (Fig. 2; Table 1). It must be underlined, however, that the diversity on the species level (21 species) is much higher than that on the genus level (seven genera). There may be fewer ammonite species because our knowledge about the dimorphism of such Late Bathonian species as Oxycerites or Choffatia is still insufficient, which may result in overestimating the ammonite species in general. During the Hodsoni Chron, apart from the genera mentioned above, there is also the beginning of domination by representatives of the genus Procerites and Choffatia in the Polish Basin.
In the following Orbis Zone, the number of ammonoid genera remains the same as in the precedent zone (seven genera), and the number of species slightly decreased to 16 species (Fig. 2; Table 1). Generally, however, the species diversity in the Orbis Zone is much higher than in any of the Lower and Middle Bathonian intervals (see Fig. 2).

\section{Diversity dynamics of ammonoids on the background of the sea-level changes during latest Bajocian and Bathonian in the Polish Basin: a discussion}

The diversity pattern of uppermost Bajocian and Bathonian ammonoids in the Polish Jura sector of the Polish Basin seems to correspond well with the sea-level changes marked on the eustatic curves of Hallam $(1988,2001)$, as well as with the majority of transgressive-regressive cycles distinguished for the Polish Lowlands by FeldmanOlszewska (1997) (see Fig. 2). It indicates that the general eustatic trend was not masked significantly by regional tectonics in the Polish Basin. During the Middle Jurassic, intense rifting leading to the gradual break-up of Pangea (e. g., Golonka 2000), and simultaneous eustatic sea-level rise may have significantly weakened the results of regional tectonics in the areas of epicratonic basins.

\section{Diversity dynamics during the latest Bajocian}

In the ammonoid assemblages dated as latest Bajocian Bomfordi Subchron, apart from dominating parkinsoniids, representatives of Phylloceratina and Lytoceratina are recorded. Generally, Phylloceratina and Lytoceratina ammonoids are characteristic components of oceanic pelagic environments (e.g., Wiedmann 1973; Ward and Signor 1983; Marcinowski and Wiedmann 1988; Lehmann 1995; Fernández-López and Meléndez 1996; Westermann 1990, 1996; Cecca 1992, 1998, 1999). There is a general agreement among Jurassic and Cretaceous ammonite workers that their maximum dispersion occurred during times of high sea-level (Wiedmann 1973, 1988; Kauffman 1977, 1984; Kennedy and Cobban 1976; Westermann 2001). In northern Europe, the transgressive pulse that begun in the Late Bajocian attained its peak at the Bajocian/Bathonian transition (Hallam 1992, 2001). In the Mediterranean Province, the transgressive phase is dated on the beginning of the Parkinsoni Chron (Sandoval et al. 2001), while in the Polish Basin a decline of the transgression is assumed (transgressive-regressive cycle J3-II of Feldman-Olszewska 1997). However, the presence of Phylloceras sp. and abundant Nannolytoceras tripartitum (Raspail) points to a regional bio-event corresponding to immigration from Tethyan areas during the Late Bajocian transgressive event (see also Zatoń and Marynowski 2006). It must also be 
added that the ammonoids mentioned above are represented by juveniles.

Fernández-López and Meléndez (1996; see also FernándezLópez and Gómez 2004) also noticed an immigration of juvenile representatives of Phylloceratina and Lytoceratina (including Nannolytoceras) during the Late Bajocian transgression. According to them, the juvenile phylloceratids and lytoceratids have not found suitable conditions for both their ontogenetic development and breeding. Although single phylloceratids, such as Calliphylloceras disputabile (Zittel), sporadically occur in the Bathonian of the Polish Jura (Zaton 2007a, 2011a, b), the representatives of Nannolytoceras no longer occur. However, Calliphylloceras is represented by incomplete phragmocones of large individuals, which may point to necroplanktic drift of their shells, or occasional, passive expansion of particular species (Fernández-López and Gómez 2004). Nannolytoceras tripartitum (Raspail) is most abundant in the uppermost Bajocian-Lower Bathonian deposits. In Hungary, this species disappears at the beginning of the Middle Bathonian (Progracilis Chron; see Galácz 1980), and in Spain, the genus Nannolytoceras is recorded until the end of the Early Bathonian (Sandoval et al. 2001). The complete absence of this genus in both the lower and higher horizons of the ore-bearing clays, even in the richest ammonite-bearing horizons (e.g., the Tenuiplicatus Zone of Kawodrza Górna and Faustianka), proves that they were short-lasting, transgression-driven immigrants not adapted for living in the epicratonic Polish Basin during those times. This hypothesis may be supported by the pattern of occurrence of the genus Lissoceras [M \& m], which is also noted as an immigrant in Spain (Fernández-López and Gómez 2004).

Representatives of the genus Nannolytoceras, as well as the Phylloceratina in general, occur abundantly in the southerly located Pieniny Basin (e.g., Wierzbowski et al. 1999; Schlögl et al. 2005). The presence of prosopid crabs associated with small oyster buildups or brachiopod lumachelles in the uppermost Bajocian ore-bearing clays point to a shallow-water environment (Krobicki and Zatoń 2008). Although water-depth may have been one of the factors limiting the development of these oceanic forms (but see Daniel et al. 1997), lower temperatures in northern areas as compared to those in Tethyan regions may have been a more likely ecological barrier for their further development (Fernández-López and Gómez 2004). The temperatures estimated on the basis of stable isotopes derived from belemnite rostra were rather low, ranging from 6 to $10^{\circ} \mathrm{C}$ during the latest Bajocian Bomfordi Chron in the Polish Jura sector of the Polish Basin (see Wierzbowski and Joachimski 2007: fig. 9). Thus, Nannolytoceras and Phylloceratina may have represented parademic populations (Fernández-López 1991; see also Fernández-López and Meléndez 1996) if their dispersion was passive, or miodemic
(Fernández-López 1991; see also Fernández-López and Meléndez 1996) if the dispersion was active. There is no indication, however, that they reached the Polish Basin by post-mortem drift as an ademic population (FernándezLópez 1991; see also Fernández-López and Meléndez 1996). The probable route of their immigration was by the Mid-Polish Trough via the East-Carpathian Gate which linked the Polish Basin with the Tethys Ocean (DayczakCalikowska and Moryc 1988; Feldman-Olszewska 1997) (Fig. 1a). At the Bajocian/Bathonian transition, on the other hand, parkinsoniids are the most numerous in north-western and central Europe (e.g., Galácz 1980; Sandoval et al. 2001), from where they migrated into the Tethyan areas (Galácz 1980). Their presence as both juveniles and adults (e.g., Matyja and Wierzbowski 2000; Zatoń and Marynowski 2006) in the Polish Basin both below and above the transgressive peak indicate that they found optimal biotic conditions favouring their development in the epicratonic Polish Basin. Therefore, they may be regarded as a eudemic population (Callomon 1985; see also Fernández-López and Meléndez 1996).

\section{Diversity dynamics during the Early Bathonian}

The low diversity noted in the Lower Bathonian Convergens Subzone correlates with a regressive episode/pulse on the sea-level curve of Hallam $(1988,2001)$ (see Fig. 2). This episode may have led to a total disappearance of the representatives of Nannolytoceras in the Polish Basin, as they are not noted subsequently. Representatives of the subgenus Parkinsonia (Parkinsonia) also slowly disappear, with only the species $P$. (P.) schloenbachi Schlippe continuing. However, the subgenus $P$. (Gonolkites), represented by the well-known species $P$. (G.) subgaleata (Buckman), appears for a short time as its occurrence is limited to the Convergens Subzone. On the other hand, $P$. (Durotrigensia), a subgenus well known since the Late Bajocian, continued into the earliest Bathonian. The reasons for low ammonoid diversity during the Yeovilensis Subchron are unclear. Despite the documented representatives of Oxycerites and Asphinctites (Kopik 1998; Matyja and Wierzbowski 2003; Zatoń 2007a, 2010a, b), some single specimens of morphoceratid genera Morphoceras and Berbericeras have been documented by Matyja and Wierzbowski (2003) and Matyja et al. (2006b). Therefore, the scarcity of ammonoids in the Yeovilensis Subzone may have resulted from taphonomic or lithological factors. In Kawodrza Górna ('Leszczyński' clay-pit; see e.g., Matyja and Wierzbowski 2000 for details), the Yeovilensis Subzone includes a thick clay sequence with a horizon of massive sideritic nodules. Therefore, on the one hand it is difficult to find and retrieve ammonites from soft, unconsolidated clays, while on the other hand, the ammonite 
fauna is rare in sideritic nodules, so that the overall ammonoid diversity within this subzone is artificially very low.

In the older Macrescens Subzone of the Zigzag Zone, and in the younger Tenuiplicatus Zone, a gradual increase of ammonoid diversity is observed (Fig. 2). In the Macrescens Subzone, six genera and nine species are recorded (Fig. 2), dominated by parkinsoniids of the subgenus Parkinsonia (Oraniceras) $[P$. (O.) gyrumbilica (Quenstedt) and $P$. (O.) wuerttembergica (Oppel)] with characteristic discoidal shells, perisphinctids (Procerites tmetolobus Buckman) and morphoceratids. At the end of the subchron, all representatives of Parkinsonia and Morphoceras disappear (see Sandoval et al. 2001).

Probably, as was mentioned above, the presence of phylloceratids in the Tenuiplicatus Zone may have resulted from their passive dispersion from Tethyan areas during a sea-level rise. The gradual increase in sea-level may have also influenced the re-immigration of Lissoceras into the Polish Basin. What is very distinctive for the Tenuiplicatus Zone in the Polish Jura is a proliferation of the two sexual dimorphs of the morphoceratid Asphinctites tenuiplicatus (Brauns) which well outnumber the rest of the ammonite species (e.g., Matyja and Wierzbowski 2000, 2001). Moreover, the macroconchs of that species are noted to be much larger in Poland than in other European localities (Matyja and Wierzbowski 2001). This distinct, regional bio-event may have resulted from optimal conditions prevailing in the area, and is probably linked to a greater nutrient supply (eutrophication) during the transgression.

Matyja and Wierzbowski (2000) have pointed out that oppeliids are much rarer than Asphinctites in the area of Częstochowa (Kawodrza Górna locality) as compared to the northern area of Faustianka. This may be explained either by a shift of the ammonite faunas from the older (Częstochowa area) to the younger one (Faustianka), or by the different locations of the both areas within the Polish Basin: more peripheral and shallower in the environs of Częstochowa where a contribution of deeper-dwelling oppeliids was smaller than in the Faustianka area (see Matyja and Wierzbowski 2000). It must be taken into account, however, that the oppeliids described by Matyja and Wierzbowski (2000) come exclusively from the Faustianka locality, while in Kawodrza Górna ('Leszczyński' clay-pit) they cited only a single fragment of Oxycerites (Matyja and Wierzbowski 2000, p. 195). The ammonite fauna collected from Kawodrza Górna (Majewski 1997; Zatoń 2007a, 2010a, b) indicates that oppeliids occur in similar quantity as in Faustianka, and thus the bathymetric differences between the both areas are insignificant. Therefore, the conclusions put forward by Matyja and Wierzbowski (2000) are based on their insufficient sampling of the Tenuiplicatus Zone at
Kawodrza Górna that simultaneously may have been biased towards more common Asphinctites specimens.

The gradual increase of ammonoid diversity beginning after the Macrescens Subchron may be related to progressive transgression during these times (transgressive-regressive cycle J3-III of Feldman-Olszewska 1997) (Fig. 2).

Diversity dynamics during the Middle Bathonian

The next transgressive peak occurs in the lower part of the Middle Bathonian (Progracilis Zone) (Fig. 2). The lack of data from epicratonic Poland, however, prevents the discussion of the ammonoid diversity within this interval. In the Subcontractus Zone, the ammonite diversity is very low. As stated above, this low diversity may be related to insufficient sampling. However, using the data in this study and the literature (Kopik 1998, 2006), it is evident that the overall ammonoid diversity during the Subcontractus Chron was low.

On the other hand, this low diversity seems to correlate with the regression phase (Fig. 2). Moreover, according to Feldman-Olszewska (1997), during the transgressiveregressive cycle J3-III during the Subcontractus Chron, a regressive pulse is well discerned in the Polish Lowlands (Fig. 2). It is worth stressing here that all European species of Tulites are recorded exclusively from the Subcontractus Zone (see Mangold and Gygi 1997). The exception is $T$. tuwaiqensis Arkell known from the Lower Bathonian of Sicily (Galácz 1999) and Saudi Arabia (Enay and Mangold 1994). However, its taxonomic status is uncertain (Galácz 1999, p. 161). If it actually belongs to the genus Tulites, as Mangold and Gygi (1997) stated, its migration toward European areas, although still problematic (see Mangold and Gygi 1997), may have been related to the progressive Early Bathonian transgression which culminated at the beginning of the Middle Bathonian (Fig. 2). The disappearance of all Tulites species, and the extinction of the genus itself, on the other hand, may have been related to an overall regression.

In the Morrisi Zone, the transition from regression (lower part of the zone) to transgression (upper part of the zone) is observed on the Hallam's curve (Fig. 2). The genus Morrisiceras, known also from England, France, Germany, Switzerland and Middle Asia (see Zatoń 2008), is going to become extinct at the end of the Middle Bathonian (in the sense of the North-European subdivision). Its extinction, similar to the case of Tulites, may have been caused by the regression-related strong restriction of shallow-marine habitats (Zatoń 2008). Such a scenario seems to be supported by the absence of Morrisiceras representatives in deeper Tethyan settings. An alternative view may be that its disappearance was related to its poor competitive abilities against the new species appearing during the Late Bathonian transgression. It is known that 'invasive' species 
may contribute to the extinction of native species (e.g., Clavero and García-Berthou 2005; see also Didham et al. 2005; Navarro et al. 2005).

\section{Diversity dynamics during the Late Bathonian}

The highest ammonoid diversity on the species level took place during the Late Bathonian (Hodsoni Chron) in the Polish Basin (Fig. 2), which correlates with the highest transgressive peak on the Hallam's $(1988,2001)$ curve and transgressive pulse in the Polish Lowlands (transgressiveregressive cycle J3-IV of Feldman-Olszewska 1997). In the Orbis chron, the number of species slightly decreases, but the overall ammonoid diversity is still very high (Fig. 2). Therefore, the highest species diversity levels during both the Hodsoni and Orbis chrons seem to be tightly correlated with the largest transgression occurring in the Late Bathonian (Fig. 2). Also, in the Late Bathonian, the Polish Basin attained the greatest width during its entire BajocianBathonian expansion history (see Dayczak-Calikowska and Moryc 1988; Matyja and Wierzbowski 2006). The high levels of species diversity may have been related to the opening of several new sea-ways that enabled migrations.

\section{Conclusions}

The ammonoid diversity during the latest Bajocian and Bathonian in the Polish Basin distinctly fluctuated in the course of particular chrons and subchrons. These changes seem to be correlated with global sea-level fluctuations, as well as with the majority of the regional transgressiveregressive cycles for the Polish Lowlands. Three main ammonoid diversity peaks (regional ammonoid bio-events) are found to be correlated with particular transgressive episodes: (1) the Latest Bajocian (Bomfordi Subchron) bioevent is related to the short-lasting immigration of Tethyan ammonoids to the epicratonic Polish Basin; (2) a late Early Bathonian (Tenuiplicatus Chron) bio-event corresponds to the proliferation of a dimorphic pair of a single species Asphinctites tenuiplicatus (Brauns), as a probable result of a transgression-driven eutrophication of shallow-marine environment; and (3) a Late Bathonian (Hodsoni and Orbis chrons) bio-event corresponds to the highest ammonoid diversity, most probably as a result of the major transgression episode during the Bathonian that allowed migration via newly opened sea-ways.

Acknowledgements The journal referees, Sixto Rafael FernándezLópez (Madrid, Spain) and Horacio Parent (Rosario, Argentina) provided constructive comments and many useful remarks improving the final version of the article, which is greatly acknowledged. I also thank Mark A. Wilson (Ohio) who, as always, was of great help to correct the language.
Open Access This article is distributed under the terms of the Creative Commons Attribution Noncommercial License which permits any noncommercial use, distribution, and reproduction in any medium, provided the original author(s) and source are credited.

\section{References}

Barski M, Dembicz K, Praszkier T (2004) Biostratygrafia i paleośrodowisko środkowej jury z kamieniołomu Ogrodzieniec. Tomy Juraj 2:61-68

Callomon JH (1985) The evolution of the Jurassic ammonite family Cardioceratidae. Spec Pap Palaeontol 33:49-90

Cecca F (1992) Ammonite habitats in the Early Tithonian of Western Tethys. Lethaia 25:257-267

Cecca F (1998) Early Cretaceous (pre-Aptian) ammonites of the Mediterranean Tethys: palaeoecology and palaeobiogeography. Palaeogeogr Palaeoclimatol Palaeoecol 138:305-323

Cecca F (1999) Palaeobiogeography of Tethyan ammonites during the Tithonian (latest Jurassic). Palaeogeogr Palaeoclimatol Palaeoecol 147:1-37

Clavero M, García-Berthou E (2005) Invasive species are a leading cause of animal extinctions. Trends Ecol Evol 20:110

Dadlez R (1989) Epikontynentalne baseny permu i mezozoiku w Polsce. Kwart Geol 33:175-198

Dadlez R (1997) Epicontinental basins in Poland: Devonian to Cretaceous - relationships between the crystalline basement and sedimentary infill. Geol Quart 41:419-432

Daniel TL, Helmuth BS, Saunders WB, Ward PD (1997) Septal complexity in ammonoid cephalopods increased mechanical risk and limited depth. Paleobiology 23:470-481

Dayczak-Calikowska K, Moryc W (1988) Rozwój basenu sedymentacyjnego i paleotektonika jury środkowej na obszarze Polski. Kwart Geol 32:117-136

Dayczak-Calikowska K, Kopik J, Myczyński R (1988) Order Ammonitida Zittel, 1884. In: Malinowska L (ed) Geology of Poland III, Atlas of guide and characteristic fossils 2b, Mesozoic - Jurassic. Wydawnictwa Geologiczne, pp 133-159

Dayczak-Calikowska K, Kopik J, Marcinkiewicz T (1997) Middle Jurassic. In: Marek S, Pajchlowa M (eds) Epikontynentalny perm i mezozoik w Polsce. Pr Państ Inst Geol 153: 236-282

Dembicz K, Praszkier T (2003) Zróżnicowanie litofacjalne osadów keloweju w rejonie Zawiercia. Tomy Juraj 1:49-52

Didham RK, Tylianakis JM, Hutchison MA et al (2005) Are invasive species the drivers of ecological change? Trends Ecol Evol 20:470-474

Dommergues J-L, Fara E, Meister C (2009) Ammonite diversity and its palaeobiogeographical structure during the early Pliensbachian (Jurassic) in the western Tethys and adjacent areas. Palaeogeogr Palaeoclimatol Palaeoecol 280:64-77

Enay R, Mangold C (1994) Première zonation par ammonites du Jura d'Arabie Saéoudite, une référence pour la province arabique. Géobios Mém Spéc 17:161-174

Feldman-Olszewska A (1997) Depositional architecture of the Polish epicontinental Middle Jurassic basin. Geol Quart 41:491-508

Fernández-López S (1991) Taphonomic concepts for a theoretical Biochronology. Rev Espan Paleontol 6:37-49

Fernández-López SR, Gómez JJ (2004) The Middle Jurassic Eastern Margin of the Iberian platform system (Eastern Spain). Palaeogeography and biodispersal routes of ammonoids. Riv Ital Paleontol Stratigr 110:151-162

Fernández-López S, Meléndez G (1996) Phylloceratina ammonoids in the Iberian Basin during the Middle Jurassic: a model of biogeographical and taphonomic dispersal related to relative sealevel changes. Palaeogeogr Palaeoclimatol Palaeoecol 120:291-302 
Galácz A (1980) Bajocian and Bathonian ammonites of Gyenespuszta Bakony Mts., Hungary. Geol Hung 39:5-227

Galácz A (1999) A lower Bathonian ammonite fauna from Erice (Western Sicily). Ann Univ Sci Budap, Sec Geol 32:149-168

Golonka J (2000) Cambrian-Neogene plate tectonic maps. Wydawnictwo Uniwersytetu Jagiellońskiego, Kraków

Hallam A (1985) A review of Mesozoic climates. J Geol Soc Lond 142:433-445

Hallam A (1987) Radiations and extinctions in relation to environmental change in the marine lower Jurassic of Northwest Europe. Paleobiology 13:152-168

Hallam A (1988) A re-evaluation of Jurassic eustasy in the light of new data and the revised Exxon curve. In: Wilgus CK, Hastings BS, Kendall CGStC et al (eds) Sea-level changes - an integrated approach. SEPM Spec Publ 42: 261-273

Hallam A (1992) Phanerozoic sea-level changes. Columbia University Press, New York

Hallam A (1996) Recovery of the marine fauna in Europe after the end-Triassic and early Toarcian mass extinctions. In: Hart, MB (ed) Biotic recovery from mass extinction events. Geol Soc Spec Publ 102: 231-236

Hallam A (2001) A review of the broad pattern of Jurassic sea-level changes and their possible causes in the light of current knowledge. Palaeogeogr Palaeoclimatol Palaeoecol 167:23-37

Hallam A, Wignall PB (1999) Mass extinctions and sea-level changes. Earth Sci Rev 48:217-250

Haq BU, Hardenbol J, Vail PR (1987) Chronology of fluctuating sea levels since the Triassic. Science 235:1156-1167

Hoedemaeker PJ (1995) Ammonite evidence for long-term seal-level fluctuations between the 2nd and 3 rd order in the lowest Cretaceous. Cretac Res 16:231-241

Kauffman EG (1977) Evolutionary rates and biostratigraphy. In: Kauffman EG, Hazel JE (eds) Concepts and methods of biostratigraphy. Hutchinson \& Ross, Dowden, pp 109-141

Kauffman EG (1984) Paleobiogeography and evolutionary response dynamic in the Cretaceous Western Interior Seaway of North America. In: Westermann GEG (ed) Jurassic-Cretaceous biochronology and paleogeography of North America. Geol Assoc Canada, Spec Paper 27: 273-306

Kennedy WJ, Cobban WA (1976) Aspects of ammonite biology, biogeography, and biostratigraphy. Spec Pap Palaeontol 17:194

Kopik J (1967) Amonity bajosu z warstw kościeliskich okolic Przystajni (Jura Krakowsko-Wieluńska). Biul Inst Geol 209:550

Kopik J (1974) Genus Cadomites Munier-Chalmas, 1892 (Ammonitina) in the Upper Bajocian and Bathonian of the Cracow-Wielun Jurassic Range and the Góry Świętokrzyskie Mountains (southern Poland). Biul Inst Geol 276:7-53

Kopik J (1979) Stratygrafia jury środkowej regionu Bełchatowa. Kwart Geol 23:179-194

Kopik J (1998) Jura dolna i środkowa północno-wschodniego obrzeżenia Górnosląskiego Zagłębia Węglowego. Biul Państw Inst Geol 378:67-120

Kopik J (2006) Bathonian ammonites of the families Sphaeroceratidae Buckman and Tulitidae Buckman from the Polish Jura Chain (Southern Poland). Pol Geol Inst Spec Papers 21:1-68

Kopik J, Dayczak-Calikowska K, Myczyński R (1980) Rząd Ammonitida Zittel, 1884. In: Malinowska L (ed) Budowa geologiczna Polski III, Atlas skamieniałości przewodnich i charakterystycznych $2 \mathrm{~b}$, Mezozoik-Jura. Wydawnictwa Geologiczne, pp 174-217

Korcz M (1973) Litologia i stratygrafia utworów bajosu okolic PorajaKamienicy Polskiej. MSc thesis

Krobicki M, Zatoń M (2008) Middle and Late Jurassic roots of brachyuran crabs: palaeoenvironmental distribution during their early evolution. Palaeogeogr Palaeoclimatol Palaeoecol 263:30-43
Kutek J, Marcinowski R (1996) Faunal changes in the Valanginian of Poland: tectonic or eustatic control? Mitt Geol-Paläont Inst Univ Hamb 77:83-88

Kutek J, Marcinowski R, Wiedmann J (1989) The Wąwał section, Central Poland - an important link between Boreal and Tethyan Valanginian. In: Wiedmann J (ed) Cretaceous of the Western Tethys. Proc 3 rd Inter Cret Symp, Tübingen 1987. Schweizerbart, Stuttgart, pp $717-754$

Lehmann J (1995) Phylloceras (Hypophylloceras) (Ammonoidea) from the Turonian of North Germany. Paläontol Z 69:401-407

Majewski W (1997) Amonity z iłów rudonośnych okolic Częstochowy. MSc thesis

Majewski W (2000) Middle Jurassic concretions from Częstochowa (Poland) as indicators of sedimentation rates. Acta Geol Pol 50:431-439

Mangold C, Gygi RA (1997) Bathonian ammonites from Canton Aargau, Northern Switzerland: Stratigraphy, taxonomy \& biogeography. Geobios 30:497-518

Marcinowski R, Gasiński A (2002) Cretaceous biogeography of epicratonic Poland and Carpathians. In: Michalik J (ed) Tethyan/Boreal Cretaceous Correlation. Mediterranean and Boreal Cretaceous paleobiogeographic areas in Central and Eastern Europe. VEDA, Bratislava, pp 95-114

Marcinowski R, Wiedmann J (1988) Paleogeographic implications of the Albian ammonite faunas of Poland. In: Wiedmann J, Kullmann J (eds) Cephalopods present and past. Schweizerbart, Stuttgart, pp 491-504

Marynowski L, Zatoń M, Simoneit BRT et al (2007) Compositions, sources and depositional environments of organic matter from the Middle Jurassic clays of Poland. Appl Geochem 22:2456-2485

Matyja BA, Wierzbowski A (2000) Ammonites and stratigraphy of the uppermost Bajocian and Lower Bathonian between Częstochowa and Wieluń, Central Poland. Acta Geol Pol 50:191-209

Matyja BA, Wierzbowski A (2001) Palaeogeographical distribution of Early Bathonian ammonites of the Asphinctites-Polysphinctites group. Hantkeniana 3:89-103

Matyja BA, Wierzbowski A (2003) Biostratygrafia amonitowa formacji częstochowskich iłów rudonośnych (najwyższy bajos górny baton) $\mathrm{z}$ odsłonięć w Częstochowie. Tomy Juraj 1:3-6

Matyja BA, Wierzbowski A (2006) European platform - Middle and Upper Jurassic. In: Wierzbowski A, Aubrecht R, Golonka J et al (eds) Jurassic of Poland and adjacent Slovakian Carpathians. Field trip guidebook of 7th International Congress on the Jurassic System Poland, Kraków, September 6-18, 2006, pp 130-132

Matyja BA, Wierzbowski A, Gedl P et al (2006a) Stop B1.5 - Sowa's and Glinski's clay pits (uppermost Bajocian-lowermost Bathonian). In: Wierzbowski A, Aubrecht R, Golonka J et al (eds) Jurassic of Poland and adjacent Slovakian Carpathians. Field trip guidebook of 7th International Congress on the Jurassic System Poland, Kraków, September 6-18, 2006, pp 149-152

Matyja BA, Wierzbowski A, Gedl P et al (2006b) Stop B1.6 Leszczyński's clay pit (Lower Bathonian). In: Wierzbowski A, Aubrecht R, Golonka J et al (eds) Jurassic of Poland and adjacent Slovakian Carpathians. Field trip guidebook of $7^{\text {th }}$ International Congress on the Jurassic System Poland, Kraków, September 618, 2006, pp 152-154

Matyja BA, Wierzbowski A, Gedl P et al (2006c) Stop B1.7 - Gnaszyn clay pit (Middle Bathonian-lowermost Upper Bathonian). In: Wierzbowski A, Aubrecht R, Golonka J et al (eds) Jurassic of Poland and adjacent Slovakian Carpathians. Field trip guidebook of 7th International Congress on the Jurassic System Poland, Kraków, September 6-18, 2006, pp 154-157

Navarro N, Neige P, Marchand D (2005) Faunal invasions as a source of morphological constraints and innovations? The diversification of the early Cardioceratidae (Ammonoidea; Middle Jurassic). Paleobiology 31:98-116 
O’Dogherty L, Sandoval J, Vera JA (2000) Ammonite faunal turnover tracing sea level changes during the Jurassic (Betic Cordillera, southern Spain). J Geol Soc Lond 157:723-736

Potocki K (1972) Litologia i stratygrafia batonu okolic Częstochowy. MSc thesis

Poulsen NS (1998) Upper Bajocian to Callovian (Jurassic) dinoflagellate cysts from central Poland. Acta Geol Pol 48:237-245

Price GD (1999) The evidence and implications of polar ice during the Mesozoic. Earth Sci Rev 48:183-210

Różycki SZ (1953) Górny dogger i dolny malm Jury KrakowskoCzęstochowskiej. Prace Inst Geol 17:1-420

Różycki SZ (1955) Parkinsonie, garantiany i strenocerasy z doggeru obrzeżenia Gór Świętokrzyskich i ich znaczenie stratygraficzne. Acta Geol Pol 5:305-341

Ruban DA (2007) Jurassic transgressions and regressions in the Caucasus (northern Neotethys Ocean) and their influences on the marine biodiversity. Palaeogeogr Palaeoclimatol Palaeoecol 251:422-436

Ruban DA (2010) Diversity dynamics of Bajocian (Middle Jurassic) ammonites and transgressions/regressions in the Caucasian Sea (northern Neo-Tethys Ocean): a case high-resolution test of probable dependence. Palaeogeogr Palaeoclimatol Palaeoecol 297:576-583

Sandoval J, O’Dogherty L, Guex J (2001) Evolutionary rates of Jurassic ammonites in relation to sea-level fluctuations. Palaios 16:311-335

Sandoval J, O'Dogherty L, Vera JA, Guex J (2002) Sea-level changes and ammonite faunal turnover during the Lias/Dogger transition in the western Tethys. Bull Soc Géol Fr 173:57-66

Saunders WB, Swan ARH (1984) Morphology and morphologic diversity of mid-Carboniferous (Namurian) ammonoids in time and space. Paleobiology 10:195-228

Schlögl J, Rakús M, Mangold C, Elmi S (2005) Bajocian-Bathonian ammonite fauna of the Czorsztyn Unit, Pieniny Klippen Belt (Western Carpathians, Slovakia); its biostratigraphical and palaeobiogeographical significance. Acta Geol Pol 55:339-359

Świdrowska J (1994) Direction of the Aalenian transgression in the area of the Mid-Polish Trough. Geol Quart 38:319-336

Szczepanik P, Witkowska M, Sawłowicz Z (2007) Geochemistry of Middle Jurassic mudstones (Kraków-Częstochowa area, southern Poland): interpretation of the depositional redox conditions. Geol Quart 51:57-66

Twitchett RJ (2006) The palaeoclimatology, palaeoecology and palaeoenvironmental analysis of mass extinction events. Palaeogeogr Palaeoclimatol Palaeoecol 232:190-213

Vermeij GJ (1995) Economics, volcanoes, and Phanerozoic revolutions. Paleobiology 21:125-152

Ward PD, Signor PW (1983) Evolutionary tempo in Jurassic and Cretaceous ammonites. Paleobiology 9:183-198

Westermann GEG (1990) New developments in ecology of JurassicCretaceous ammonoids. In: Pallini G, Cecca F, Cresta S, Santantonio M (eds) Atti del secondo convegno internazionale Fossili Evoluzione Ambiente, Pergola, pp 459-478

Westermann GEG (1996) Ammonoid life and habitat. In: Landman NH, Tanabe K, Davis RA (eds) Ammonoid paleobiology. Topics in geobiology. Academic Press, New York, pp 607-707
Westermann GEG (2001) Modes of extinction, pseudo-extinction and distribution in the Middle Jurassic ammonites: terminology. Can J Earth Sci 38:187-195

Wiedmann J (1973) Evolution or revolution of ammonoids at Mesozoic system boundaries. Biol Rev 48:159-194

Wiedmann J (1988) Plate tectonics, see level changes, climate - and the relationship to ammonite evolution, provincialism, and mode of life. In: Wiedmann J, Kullmann J (eds) Cephalopods - present and past. Schweizerbart, Stuttgart, pp 737-735

Wiedmann J, Kullmann J (1996) Crises in ammonoid evolution. In: Landman NH, Tanabe K, Davis RA (eds) Ammonoid paleobiology. Topics in geobiology. Academic Press, New York, pp 795-813

Wierzbowski H, Joachimski M (2007) Reconstruction of late BajocianBathonian marine palaeoenvironments using carbon and oxygen isotope ratios of calcareous fossils from the Polish Jura Chain (central Poland). Palaeogeogr Palaeoclimatol Palaeoecol 254:523540

Wierzbowski A, Jaworska M, Krobicki M (1999) Jurassic (Upper Bajocian-lowest Oxfordian) ammonitico rosso facies in the Pieniny Klippen Belt, Carpathians, Poland: its fauna, age, microfacies and sedimentary environment. Stud Geol Pol 115:7-74

Zatoń M (2007a) Amonity z iłów rudonośnych (bajos-baton) Jury Polskiej. $\mathrm{PhD}$ thesis

Zatoń M (2007b) Tulites cadus Buckman, 1921 (Ammonoidea) from the Middle Bathonian of the Polish Jura and its biostratigraphic significance. N Jahrb Geol Pal Abh 243:191-199

Zatoń M (2008) Taxonomy and palaeobiology of the Bathonian (Middle Jurassic) tulitid ammonite Morrisiceras. Geobios 41:699-717

Zatoń M (2010a) Bajocian-Bathonian (Middle Jurassic) ammonites from the Polish Jura. Part 1: Families Phylloceratidae, Nannolytoceratidae, Sonniniidae, Strigoceratidae, Oppeliidae and Lissoceratidae. Palaeontogr, Abt. A 292:65-113

Zatoń M (2010b) Bajocian-Bathonian (Middle Jurassic) ammonites from the Polish Jura. Part 2: Families Stephanoceratidae, Perisphinctidae, Parkinsoniidae, Morphoceratidae and Tulitidae. Palaeontogr, Abt. A 292:115-213

Zatoń M, Marynowski L (2006) Ammonite fauna from uppermost Bajocian (Middle Jurassic) calcitic concretions from the Polish Jura - biogeographical and taphonomical implications. Geobios 39:426-442

Zatoń M, Taylor PD (2009a) Middle Jurassic cyclostome bryozoans from the Polish Jura. Acta Palaeontol Polon 54:267-288

Zatoń M, Taylor PD (2009b) Microconchids (Tentaculita) from the Middle Jurassic of Poland. Bull Geosci 84:653-660

Zatoń M, Taylor PD (2010) Bathonian (Middle Jurassic) cyclostome bryozoans from the Polish Jura. Bull Geosci 85:275-302

Zatoń M, Marynowski L, Bzowska G (2006) Konkrecje hiatusowe z iłów rudonośnych Wyżyny Krakowsko-Częstochowskiej. Przeg Geol 54:131-138

Zatoń M, Marynowski L, Szczepanik P et al (2009) Redox conditions during sedimentation of the Middle Jurassic (Upper BajocianBathonian) clays of the Polish Jura (south-central Poland). Facies 55:103-114

Ziegler PA (1990) Geological atlas of western and central Europe. Shell Internationale Petroleum Maatschappij 